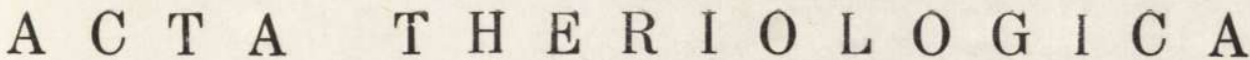

VOL. XI, 17: 391-398.

BIAŁOWIEŻA

15.XII.1966

Marek GĘ B C Z Y N S K I

\section{The Daily Energy Requirement of the Yellow-necked Field Mouse in Difierent Seasons ${ }^{1}$ )}

[With 3 Tables \& 3 Figs.]

The daily energy requirement of the yellow-necked field mouse is $0.467 \mathrm{Kcal} / \mathrm{g} /$ day in summer, 0.551 in autumn, 0.413 in winter and 0.505 in spring. This was calculated from the mean daily oxygen consumption with the corrections for the influence of temperature on heat production (thermoregulation) and the increased requirement during the gestation and lactation. The daily energy budget of field mice from the Białowieża population in summer is $12.347 \mathrm{Kcal} /$ animal/day (mean body weight $-26.44 \mathrm{~g})$, in autumn $-15.747(28.58 \mathrm{~g})$, in winter $11.176(27.06 \mathrm{~g})$ and in spring $-12.130(24.02)$.

\section{INTRODUCTION}

To calculate the energy flow through the rodent population it is necessary to know their daily energy requirement. The cost of maintenance can be most easily determined by measuring the oxygen consumption. The purpose of this investigation was to determine these values for the yellow-necked field mouse, Apodemus fiavicollis (Melchior, 1834) which is one of two dominating rodent species in the deciduous forests of the european temperate zone. The daily bioenergetic was computed from the average daily metabolic rate $(A D M R)$ and the heat production in different temperatures.

\section{MATERIALS AND METHODS}

The mice were caught in the Białowieża National Park in the deciduous forest Querco-Carpinetum medioeuropaeum Tx. Before the experiment mice were kept in the laboratory from 2 to 3 days ${ }^{2}$ ).

1) This study was carried out under the Rodent Project of the International Biological Programme in Poland.

2) The methods of the experiments were given by Dr. W. Grodzinski in the "Program of bioenergetic studies concerning the productivity of small rodents" 1965, MS. 
During this period and during the experiments animals were fed oats and beets. The oxygen consumption was measured in the closed-circuit type respirometer (Gę bczyński, 1963). In 24 hour experiments the mice were kept singly in 14.41 chambers. In this way the oxygen consumption of 72 animals was measured (T'able 1). Besides, the 40 minute measurements of oxygen consumption were done at the temperatures $5-9,15$ and $25^{\circ} \mathrm{C}$. In these experiments the mice were placed singly in small cages restricting their movements. The total of 171 measurements were done using $12-16$ animals at the time.

Table 1.

The number of animals studied in different seasons.

\begin{tabular}{|l|c|rr|r|r|c|}
\hline \multicolumn{1}{|c|}{ Season } & $\mathrm{n}$ & of & $\mathrm{O}^{*} \mathrm{O}^{*}$ & $\begin{array}{c}\text { Body } \\
\text { weight (g) }\end{array}$ & $\pm \sigma$ & $\begin{array}{c}\text { Coeff. } \\
\text { Variat. (\%) }\end{array}$ \\
\hline Summer (July) & 20 & 10 & 10 & 31.77 & 2.51 & 12.55 \\
Autumn (Oct.-Nov.) & 12 & 6 & 6 & 35.09 & 2.39 & 19.91 \\
Winter (Jan.) & 20 & 10 & 10 & 34.10 & 3.83 & 19.15 \\
Spring (Apr.-May) & 20 & 9 & 11 & 38.34 & 2.11 & 10.55 \\
\hline
\end{tabular}

The whole day measurements lasting 25-26 hours allowed indirect studies of the daily activity rhythm. The length of day in the experiment was 16 hours in summer, 8 in winter and 12 in spring and autumn similar to the natural day length.

\section{THE OXYGEN CONSUMPTION IN DIFFERENT SEASONS}

The average daily metabolic rate of the field mouse expressed in the mean oxygen consumption, was the highest in the autumn and the lowest in the winter. The spring and summer values were intermediate (Table 2 -. see page 395). However, the differences in $A D M R$ are connected also with the body weight which varies with the season. Considering the body weight (Fig. 1) the oxygen consumption in the summer and in the winter was almost identical. Similarly, there was very little difference in $A D M R$ between autumn and spring but in these two seasons the values were higher. To summarize, the $A D M R$ was highest in the spring, slightly lower in the autumn and considerably lower in both winter and summer (Fig. 1).

The value of metabolism in different temperatures was similar during the spring, summer and autumn. Only the oxygen consumption at $25^{\circ} \mathrm{C}$ in summer was different having the lowest value (Fig. 2). This difference was significant. In winter at the temperatures 6 and $15^{\circ} \mathrm{C}$ the yellownecked mice had significantly lower level of oxygen consumption than in summer (Table 2 - the comparisons were made for the temperatures 6 and $15^{\circ}$ interpolating the corresponding winter values). The decrease of oxygen consumption in the summer at $25^{\circ}$ and in the winter at 5 and $15^{\circ}$ 
indicates that $A$. flavicollis possesses good chemical thermoregulation (heat production) which differs from season to season.. These results are somewhat different from the data of $\mathrm{Ka} \mathrm{la} \mathrm{bukhov}$ et al. (1950) who reported that within the range of 5 to $20^{\circ}$ the oxygen consumption was

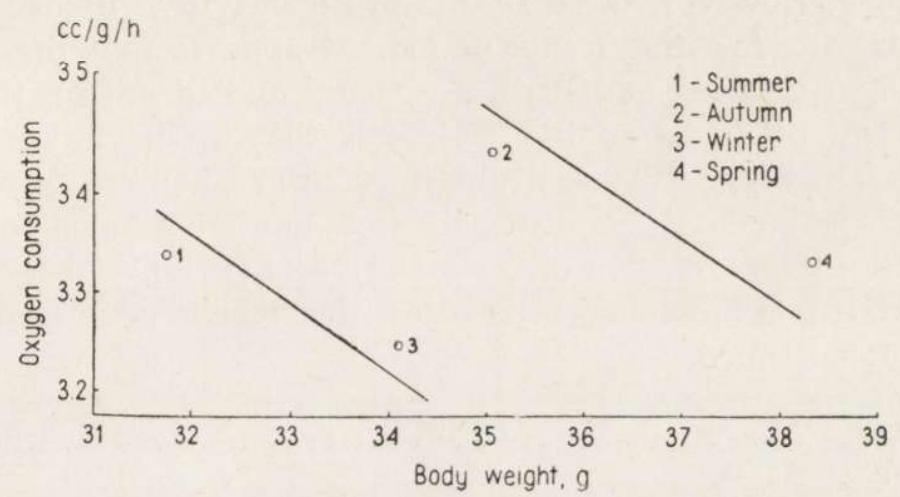

Fig. 1. The dependence between the value of $A D M R$ and body weight in different seasons.

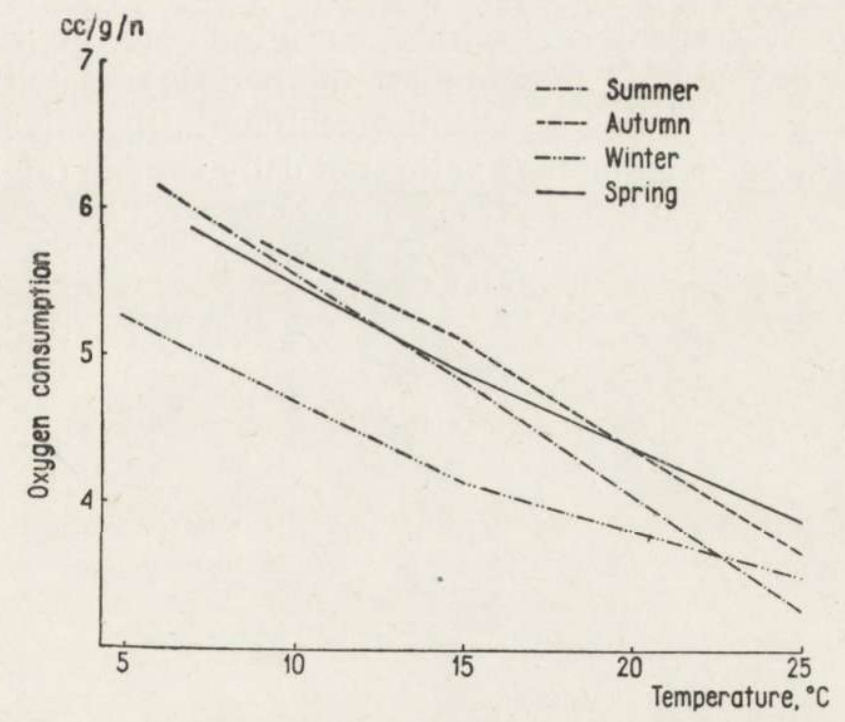

Fig. 2. The influence of temperature on the heat production in the yellow-necked field mouse in different seasons.

higher in the summer than in the autumn and winter and that the autumn and winter values were very similar. This seasonal differences in the chemical thermoregulation were most likely caused by studying the animals from a completely different climate (Caucasus, Turkmania and Iran). 
The average daily metabolic rate is lower than the interpolated value of resting metabolism rate $(R M R)$ for $20^{\circ}$. For example in the winter it was about $3.8 \mathrm{cc} / \mathrm{g} / \mathrm{h}$. This agrees well with the value of $R M R$ determined for the same species by G r o d z i ń sk i (1961) - $4.4 \mathrm{cc} / \mathrm{g} / \mathrm{h}$ for the body weight $28.8 \mathrm{~g}$. However, these results are about $18 \%$ higher than the value of $A D M R$ for the same period. It appears that the periods of minimal activity (sleep and rest) are long and decrease the overall oxygen consumption. In addition it seems that in short time measurements of $R M R$, which are usually performed in small chambers without the nest, the animals are excited and their muscular tonus is increased. Consequently, the conclusion of G r o d z i n s k i (1966), that the measurement of $A D M R$ is most convenient for the bioenergetic computations, seems fully confirmed.

\section{THE CALCULATION OF DAILY CALORIC REQUIREMENT}

The value of $A D M R$ determined in 24 hour experiments using large chambers and a relatively large number of animals differing in respect to sex, age and body weight, allows to compute the energy requirement. However, several corrections have to be introduced. First of all, the measurements of this type are summing the periods of activity and the periods of rest in the nest, consequently resulting in the value somewhat below the RMR. The well marked pattern of daily rhythm (Fig. 3) clearly

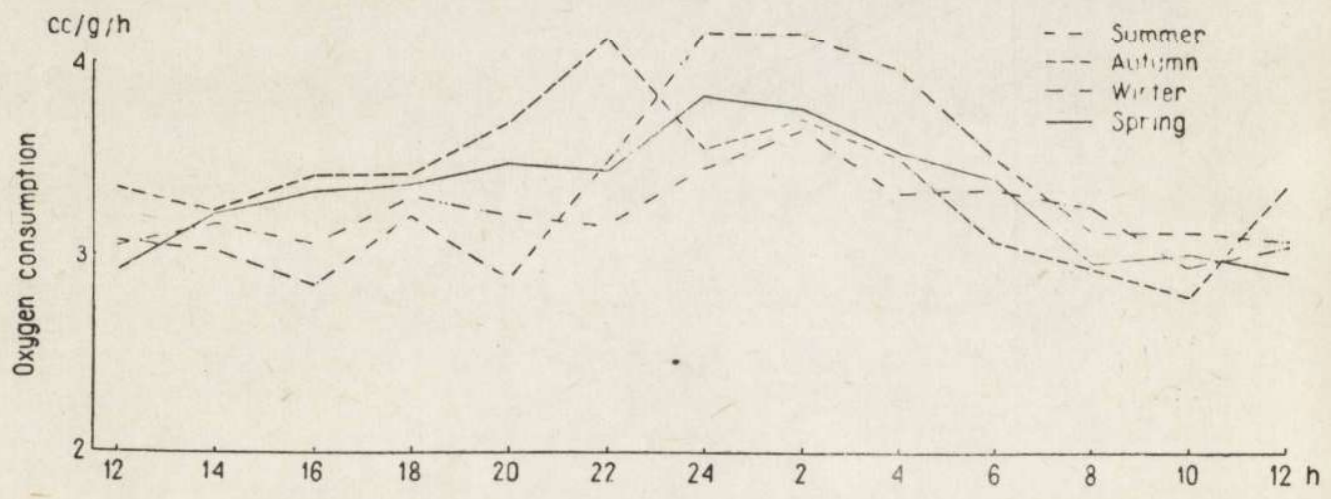

Fig. 3. The daily rhythm of the yellow-necked field mouse in different seasons.

indicates that the animals were active during the experiment. As an example it was computed that the field mouse in the summer uses $13 \%$ of total energy for the activity in the night. $\mathrm{M} \mathrm{c} \mathrm{N} \mathrm{a} \mathrm{b} \mathrm{(1963)} \mathrm{reported}$ that the Peromyscus of the same body weight uses about $15 \%$ of the whole daily budget for the activity. 
The measurements of $A D M R$ were done in the temperature $20^{\circ} \mathrm{C}$ which is probably very close to the temperature in the nest of a field mouse. In the nest of Clethrionomys glareolus the temperature ranges from 17 to $19^{\circ}$ (Danie l, 1964). However, A. flavicollis prefers the temperature of $20.34^{\circ}$ (after $\mathrm{Ka} \mathrm{la} \mathrm{bukhov}, 1951$ ). Consequently, the influence of temperature should be considered only during the periods of activity outside the nest.

The data of Kowalski (1951), Ostermann (1956), Buchalczyk (1964) and the results of this investigation (Fig. 3) indicate that in central Europe in summer field mice are active for 6-8 hours during the night. During the night the temperature in Querco-carpinetum measured $20 \mathrm{~cm}$ above the ground is, on the average, $14.4^{\circ}$ and ranges from 13.8 to $16.6^{\circ}$ (all climatic data collected by the Mammals Research Institute). From the slope of the chemical thermoregulation curve (Fig. 2) it is possible to calculate that during the summer the decrease of ambient temperature by $5.6^{\circ}$ (from 20 to $14.4^{\circ}$ ) results in the $25 \%$ increase of the oxygen consumption. Consequently, during this period, the value of $A D M R$ should be $4.2 \mathrm{cc} / \mathrm{g} / \mathrm{h}$. It amounts to $0.95 \mathrm{Kcal} / \mathrm{g}$ per 8 hours or $0.029 \mathrm{Kcal} / \mathrm{g} /$ day (Table 2 ).

It was noted by Olszewski (personal communication) that in the natural circumstances the activity of mice is increased because of the contacts with individuals of both the same and different species. However, this correction is probably balanced by the decrease of metabolism resulting from the gathering of many animals in the same nest (P e a r- . s on, 1960; P on uga eva, 1960).

Table 2.

The value of average daily metabolic rate $(A D M R)$, the corrections for heat production in different temperatures (all seasons) and for the gestation and lactation (spring, summer and autumn) and the daily energy requirement of the yellow-necked field mouse.

\begin{tabular}{|l|c|c|c|c|c|c|}
\hline \multirow{2}{*}{ Season } & ADMR & $\pm \sigma$ & ADMR & $\begin{array}{c}\text { Heat } \\
\text { production }\end{array}$ & $\begin{array}{c}\text { Gestation } \\
\text { \& lactation }\end{array}$ & $\begin{array}{c}\text { Daily } \\
\text { requirement }\end{array}$ \\
\hline Summer & 3.368 & 0.89 & 0.388 & 0.029 & 0.050 & 0.467 \\
Autumn & 3.447 & 0.21 & 0.397 & 0.103 & 0.051 & 0.551 \\
Winter & 3.249 & 0.34 & 0.374 & 0.039 & - & 0.413 \\
Spring & 3.344 & 0.46 & 0.385 & 0.070 & 0.050 & 0.505 \\
\hline
\end{tabular}

Therefore, it appears sufficient to add only the increased energy expenditures connected with the periods of gestation and lactation. In bank vole, Clethrionomys glareolus this correction is, on the average, $24 \%$ for gestation and $92 \%$ for lactation ( $\mathrm{K} \mathrm{a} \mathrm{c} \mathrm{z} \mathrm{mar} \mathrm{s} \mathrm{k} \mathrm{i,} \mathrm{1966).} \mathrm{Assum-}$ 
ing that the increase of metabolism in A. flavicollis is similar and that all females ( $50 \%$ of population) have the average of three litters yearly, with the gestation period of 24 and lactation of 20 days, the increase for the whole population in the spring, summer and autumn would be about $13 \%$. Consequently, considering corrections for both the heat production during out-of-the-nest activity and the period of gestation and lactation, the daily requirement in the summer is $0.467 \mathrm{Kcal} / \mathrm{g}$ (Table 2).

In spring and autumn the correction for moulting should be also considered. However, there is no data on the increase of energy requirement during the moult.

In autumn the increase of activity of Apodemus flavicollis during the night is not as strongly pronounced as in summer but the night period of activity is longer and amounts to $10-12$ hours (K ow als k i, 1951; Ostermann, 1956; Buchalczyk, 1964). Considerable activity of the mice in this period is connected with making stores of food ( $\mathrm{P}$ on ug a eva, 1960). The air temperature in Querco-carpinetum $20 \mathrm{~cm}$ above

\section{Table 3.}

The resting metabolism rate $(R M R)$ of the yelow-necked field mouse in different temperatures and different season.

In the range from 5 to $9^{\circ}$ the precise temperature of the measurement is given in parenthesis for every season.

\begin{tabular}{|l|c|c|c|c|c|c|}
\hline \multirow{2}{*}{ Season } & \multicolumn{2}{|c|}{$25^{\circ}$} & \multicolumn{2}{|c|}{$15^{\circ}$} & \multicolumn{2}{|c|}{$5-9^{\circ}$} \\
\cline { 2 - 3 } & $\mathrm{cc} / \mathrm{g} / \mathrm{h}$ & $\begin{array}{r}\text { Body weight } \\
\text { (g) }\end{array}$ & $\mathrm{cc} / \mathrm{g} / \mathrm{h}$ & $\begin{array}{r}\text { Body weight } \\
\text { (g) }\end{array}$ & $\mathrm{cc} / \mathrm{g} / \mathrm{h}$ & $\begin{array}{c}\text { Body weight } \\
\text { (g) }\end{array}$ \\
\hline Summer & 3.28 & 33.25 & 4.83 & 33.11 & $6.15\left(6^{\circ}\right)$ & 28.61 \\
Autumn & 3.67 & 36.41 & 5.11 & 37.72 & $5.76\left(9^{\circ}\right)$ & 35.65 \\
Winter & 3.50 & 37.41 & 4.15 & 37.46 & $5.26\left(5^{\circ}\right)$ & 36.86 \\
Spring & 3.05 & 39.25 & 4.89 & 39.31 & $5.86\left(7^{\circ}\right)$ & 39.44 \\
\hline
\end{tabular}

the ground is $4.3^{\circ}$ ranging from 3.7 to $5.7^{\circ}$. The decrease of ambient temperature by $15.7^{\circ}$ results in a 57 per cent increase of oxygen consumption and, consequently the $A D M R$ during the periods of out-of-the-nest activity should amount to $5.4 \mathrm{cc} / \mathrm{g} / \mathrm{h}$. This corresponds to 3.7 $\mathrm{Kcal} / \mathrm{g} /$ day. With the correction for gestation and lactation the energy requirement is $0.551 \mathrm{Kcal} / \mathrm{g} /$ day (Table 2).

In the winter the air temperature is low $\left(-4.7^{\circ}\right)$ but the temperature under the snow ranges from 0 to $+5^{\circ}(\mathrm{Judin}, 1962$; C oulian os \& Johnels, 1962). This latter value should be used for calculating the correction as in the winter the mice remain under the snow. It appears, that mice are less active during the winter than in other seasons. Their daily rhythm is least pronounced (O s te r m a n n, 1956; Fig. 3). Assuming that they stay outside the nest for 3 to 5 hours daily, the correction 
is $1.33 \mathrm{Kcal}$. This low value of the correction is partially due to the fact that at $0^{\circ}$ their metabolism increases very moderately (the value extrapolated from Table 3 ). Consequently, in the winter the energy requirement is the lowest and amounts only to $0.413 \mathrm{Kcal} / \mathrm{g} / \mathrm{day}$. This low value reflects also the interruption of reproduction during the winter (the correction for gestation and lactation was not added - Table 2).

In the spring the correction computed in the same way as described above is $2.7 \mathrm{Kcal}$. The energy requirement considering the corrections for reproduction is slightly lower than in the autumn and amounts to $0.505 \mathrm{Kcal} / \mathrm{g} /$ day (Table 2 ).

\section{DISCUSSION}

T u r ček (1956) measured the food consumption of A. flavicollis captured in the spring and the summer and kept in laboratory conditions. $\mathrm{He}$ calculated that the mice were using 0.609 or $0.639 \mathrm{Kcal} / \mathrm{g} /$ day depending on the kind of seeds consumed. This agrees very well with the data presented above. However, the direct comparison is difficult as the experiments of $\mathrm{T} u \mathrm{r} c \mathrm{ek}$ were carried out on seven specimens kept for several months in the laboratory.

To calculate the energy flow from the above data it is necessary to multiply the daily energy requirement by the mean state of biomass, i.e. the population numbers $X$ mean body weight. Considering large seasonal differences in the energy requirement it seems appropriate to compute the energy flow separately for every season. As an example, the energy requirement of one field mouse was calculated using the values of body weight reported for the Białowieża population by $\mathrm{Adam}$ c z e w ska (1959). For the summer months (July, August and September; $\mathrm{n}=1270$ ) the mean body weight was $26.44 \mathrm{~g}$ and the energy requirement $12.347 \mathrm{Kcal} /$ animal/day. In the autumn (October, November and March; $\mathrm{n}=61)$ the corresponding values were $27.06 \mathrm{~g}$ and $11.176 \mathrm{Kcal} /$ /animal/day and in the spring (April, May and June; $\mathrm{n}=225$ ) $24.02 \mathrm{~g}$ and $12.130 \mathrm{Kcal} / \mathrm{animal} / \mathrm{day}$. Multiplying these results by the population numbers per area unit would result in the value of energy flow.

\section{REFERENCES}

1. A damczewska K., 1959: Untersuchungen über die Variabilität der Gelbhalsmaus, Apodemus flavicollis flavicollis (M elchior, 1834). Acta theriol. 3, 10: $141-190$.

2. Buchalczyk T., 1964: Daily activity rhythm in rodents under natural conditions. Acta theriol. 9, 20: 357-362.

3. Coulianos C. C. \& Johnels A. G., 1962: Note on the subnivean environment of small mammals. Ark. Zool. 2, 15, 24: 363-370. 
4. Daniel M., 1964: Temperature and humidity in the nest of Clethrionomys glareolus observed in continuous experiment. Acta Soc. zool. Bohemoslov. 28, 3: 278-279.

5. Gębczyński M., 1963: Apparatus for daily measurements of oxygen consumption in small mammals. Bull. Acad. pol. Sci., Cl. II, 11, 9: 433-435.

6. Grodziński W., 1961: Metabolism rate and bioenergetics of small rodents from the deciduous forest. Bull. Acad. pol. Sci., Cl. II, 9, 12: 493-499.

7. Grodziński W., 1966: Bioenergetics of small mammals from the Alaskan taiga forest. Lynx 6: 47-51.

8. J u din B. S., 1962: Ekologija burozubok (rod Sorex) Zapadnoj Sibirii. A. N. SSSR, Sibirskoe Otd., Tr. biol. in-ta, 8: 33-134.

9. Kaczmarski F., 1966: Bioenergetics of pregnancy and lactation in the bank vole. Acta theriol. 11, 19: 409-417.

10. K a la bukhov N. I., 1951: Metodika eksperimentalnyh issleđovanij po e'kologii nazemnyh poznonočnyh. Izd. Sovetskaja nauka: 1-176.

11. Kalabukhov N. I., Ladygina N. M. \& Mejzelis M. R., 1951: Sezonnye izmenenija reakcii na temperaturu nekotoryh vidov myšej $i$ homjakov. Tr. I Vsesojuz. sov. po gryzunam. Zool. inst. AN SSSR.

12. Kowalski K., 1951: Rytmika dobowa aktywności gryzoni Clethrionomys glareolus glareolus $\mathrm{Schreber}$ i Sylvimus flavicollis flavicollis $\mathrm{Melch}$ ior i jej zależność od warunków oświetlenia. Rozpr. Wydz. Mat. Przyr. PAU, B, 74, 4: $151-187$.

13. M c N a b B. K., 1963: A model of the energy budget of wild mouse. Ecology 44, 3: $521-532$.

14. O sterma n n K., 1956: Zur Aktivität heimischer Muriden und Gliriden. Zool. Jb. (Physiol.), 66, 2-3: 355-388.

15. Pears on O. P., 1960: The oxygen consumption and bioenergetics of harvest mice. Physiol. Zool. 33, 2: 152-160.

16. Ponugaeva A. G., 1960: Fiziologičeskie issledovanija instinktov u mlekopitajuščih. Izd. AN SSSR: 1-180. Moskva-Leningrad.

17. Tur ček F. J., 1956: Quantitative experiments on the consumption of tree-seeds by mice of the species Apodemus flavicollis. Ann. zool. Soc. "Vanamo" 10, 1: $50-59$.

Received, April 25, 1966.

Polish Academy of Sciences,

Mammals Research Institute,

Białowieża, Poland.

Marek GĘBCZYÑSKI

DOBOWE ZAPOTRZEBOWANIE ENERGETYCZNE MYSZY LESNEJ W RÓŻNYCH SEZONACH

Streszczenie

Dobowe zapotrzebowanie myszy leśnej Apodemus flavicollis ( $\mathrm{Mel} \mathrm{ch}$ i or, 1834) wynosi latem $0,467 \mathrm{Kcal} / \mathrm{g} /$ dobę, jesienią odpowiednio 0,551 , zimą 0,413 , wiosną 0,505 . Zapotrzebowanie to obliczono na podstawie średniego dobowego zużycia tlenu (Tabela 1,2), doliczając poprawki na termoregulację (Tabela 3, Ryc. 2) i wzmożone wydatki związane $\mathrm{z}$ okresem ciąży i karmienia. W ten sposób budżet dobowy myszy leśnych o wielkości charakterystycznej dla populacji białowieskiej wynosi latem $12,347 \mathrm{Kcal} / \mathrm{zwierzę/dobę} \mathrm{(średni} \mathrm{ciężar} \mathrm{ciała}-26,44 \mathrm{~g}$ ), jesienią odpowiednio $15,747(28.58 \mathrm{~g})$, zimą $11,176(27,06 \mathrm{~g})$, wiosną $12,130(24,02 \mathrm{~g})$. 